
POMATIAS ELEGANS (MÜLLER).

\author{
By Dr. A. E. Bоусотт, F.R.S., etc.
}

Read 10th November, 1916.

Some years since ${ }^{1}$ I examined the shells of a series of Pomatias elegans from Ashtead in Surrey for sexual characters and found that the females were longer and wider than the males, but not more tumid, i.e. the ratio of length to breadth was the same in the two sexes. In the present communication I give the results of the examination of some 400 specimens, collected on about a hundred yards length of chalky hedge bank in the parish of St. Stephen, near Aldenham, in Hertfordshire, on 28th June and 1st July, 1916, when they were crawling freely on the surface after rain. All specimens found were taken without selection. The two lots were analysed separately, but no significant difference was found in any respect and they are treated below as forming one series. ${ }^{2}$

The shells were measured with sliding callipers to $0.1 \mathrm{~mm}$, the length (altitude) being taken parallel to the axis of the shell and the breadth (diameter) at right angles to the length. The fraction $\frac{\text { altitude }}{\text { diameter }} \times 100$ gives a measure of tumidity. These figures do not of course afford a complete description of the shells; with regard to the shape of whorls, depth of suture, size and shape of mouth, and the like, I can only say that by visual inspection I can detect no difference between males and females.

In comparing males and females it is necessary in the first instance to take only mature specimens, and as the criterion of maturity the completion of the peristome has been used. ${ }^{3}$ There will obviously be a certain number of specimens in which it is a matter of opinion rather than of fact whether the peristome is complete or not; but such specimens are few in number, and, noting also the texture of the edge of the shell and the depth within the mouth where the operculum makes a good fit, there does not seem to be much danger of any substantial inconsistency in the determination of maturity, at any rate within the same series of shells examined at

1 Journal of Conchology, vol. xii, 1909, p. 323.

2 e.g. in the first lot males formed 54 per cent of 130 mature specimens, in the second 61 per cent of 187 , a difference easily compatible with the two lots being random samples of the same series.

${ }^{3}$ I do not know whether sexual activity is restricted to individuals which are mature by this standard; anatomically the sexual apparatus seems to be pretty fully developed in the larger immature specimens (e.g. in many of the males of $11.5 \mathrm{~mm}$. altitude). In species where the growth of the shell reaches a definitive termination (e.g. Tachea), completion of the shell seems to precede sexual action. The six pairs taken in cop. in the present series were all mature. 
one time. Unless otherwise stated, the following refers to specimens judged to be mature in this way.

Of 317 specimens, 184 ( 58 per cent) were males and 133 (42 per cent) females.

\section{Altitude and Diameter.}

The altitudes and diameters, distributed in convenient groups of $0.3 \mathrm{~mm}$., are shown in the table, which gives also the relation between altitude and diameter for each group.

\begin{tabular}{|c|c|c|c|c|c|c|c|c|c|c|c|c|c|c|}
\hline & \multicolumn{10}{|c|}{ DIAMETER $\mathrm{mm}$. } & \multirow[b]{2}{*}{$\frac{\dot{0}}{\frac{0}{3}}$} & \multirow[b]{2}{*}{ 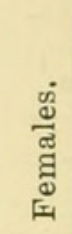 } & \multirow[b]{2}{*}{ 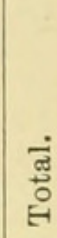 } \\
\hline & & $\begin{array}{l}\infty \\
\dot{0} \\
0 \\
\dot{\infty}\end{array}$ & $\begin{array}{l}\vec{\phi} \\
\dot{1} \\
\dot{\infty}\end{array}$ & $\begin{array}{l}\ddot{1} \\
\dot{0} \\
\dot{\alpha} \\
\dot{0}\end{array}$ & $\begin{array}{l}\overrightarrow{5} \\
\dot{1} \\
\dot{\sigma}\end{array}$ & $\begin{array}{l}\dot{0} \\
\dot{\sigma} \\
\dot{1} \\
\dot{\sigma}\end{array}$ & $\begin{array}{l}m \\
\dot{0} \\
\dot{1} \\
\dot{0}\end{array}$ & $\begin{array}{l}\dot{0} \\
\dot{0} \\
\dot{I} \\
\dot{0}\end{array}$ & $\begin{array}{l}\dot{0} \\
\dot{0} \\
1 \\
\dot{1} \\
\dot{0}\end{array}$ & $\begin{array}{l}\stackrel{9}{\dot{\sigma}} \\
\bar{\jmath} \\
\dot{\Xi}\end{array}$ & 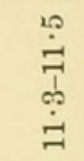 & & & \\
\hline 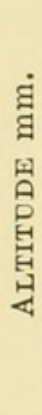 & $\begin{array}{l}12 \cdot 0-12 \cdot 2 \\
12 \cdot 3-12 \cdot 5 \\
12 \cdot 6-12 \cdot 8 \\
12 \cdot 9-13 \cdot 1 \\
13 \cdot 2-13 \cdot 4 \\
13 \cdot 5-13 \cdot 7 \\
13 \cdot 8-14 \cdot 0 \\
14 \cdot 1-14 \cdot 3 \\
14 \cdot 4-14 \cdot 6 \\
14 \cdot 7-14 \cdot 9 \\
15 \cdot 0-15 \cdot 2 \\
15 \cdot 3-15 \cdot 5 \\
15 \cdot 6-15 \cdot 8\end{array}$ & $\begin{array}{l}4+0 \\
8+0 \\
1+o\end{array}$ & $\begin{array}{r}3+o \\
7+o \\
11+o \\
5+o \\
3+0\end{array}$ & $\begin{array}{r}1+o \\
11+0 \\
11+0 \\
19+1 \\
4+2\end{array}$ & $\begin{array}{r}4+0 \\
9+0 \\
17+\mathrm{r} \\
20+7 \\
7+2 \\
0+3 \\
1+0\end{array}$ & $\begin{array}{c}3+o \\
5+o \\
13+6 \\
7+6 \\
2+13 \\
0+1 \\
0+2\end{array}$ & $\begin{array}{l}1+0 \\
2+3 \\
5+6 \\
0+7 \\
0+\text { Io } \\
0+6 \\
0+1\end{array}$ & $\begin{array}{l}0+\mathbf{I} \\
0+3 \\
0+6 \\
0+7 \\
0+3 \\
0+6 \\
0+3\end{array}$ & $\begin{array}{l}0+5 \\
0+5 \\
0+4 \\
0+3 \\
0+3\end{array}$ & $\begin{array}{l}0+\mathbf{I} \\
0+2 \\
0+\mathrm{I} \\
0+\mathrm{I} \\
0+\mathrm{I}\end{array}$ & $0+\mathrm{I}$ & $\begin{array}{r}3 \\
12 \\
34 \\
28 \\
46 \\
39 \\
19 \\
2 \\
1\end{array}$ & $\begin{array}{r}2 \\
19 \\
17 \\
34 \\
24 \\
17 \\
11 \\
7 \\
2\end{array}$ & $\begin{array}{r}3 \\
12 \\
34 \\
28 \\
48 \\
58 \\
36 \\
36 \\
25 \\
17 \\
11 \\
7 \\
2\end{array}$ \\
\hline & ales. : & 13 & 29 & $\begin{array}{r}46 \\
3\end{array}$ & $\begin{array}{l}58 \\
1_{3}\end{array}$ & $\begin{array}{l}30 \\
28\end{array}$ & $\begin{array}{r}8 \\
33\end{array}$ & 29 & 20 & 6 & I & 184 & $\mathrm{I}_{33}$ & \\
\hline & tal . . . & 13 & 29 & 49 & 71 & 58 & 41 & 29 & 20 & 6 & 1 & & & 317 \\
\hline
\end{tabular}

$" 13+6 "=13$ males, 6 females.

Further analysis of these figures gives the following summary results :-

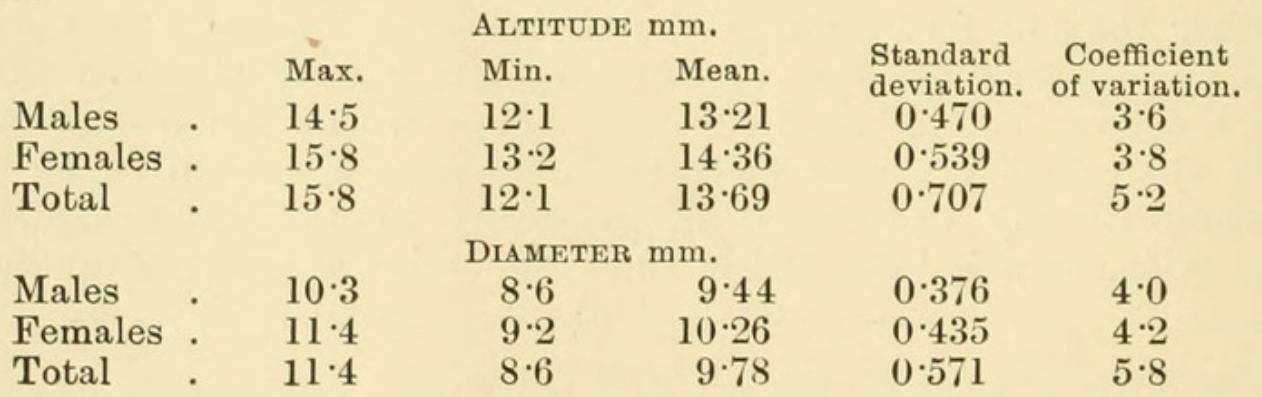

It is clear from these results ${ }^{1}$ that the females are definitely larger than the males. Of the males 77 of 184 (42 per cent) are smaller (in altitude) than the smallest female, and of the females 47 of 133

${ }^{1}$ For statistical methods and the interpretation of the results I have followed G. U. Yule, Introduction to the Study of Statistics (2nd ed., London, 1912), where a plain account of the methods of testing the validity of numerical differences will be found. 
(35 per cent) are larger than the largest male, the average female being $1.2 \mathrm{~mm}$. longer and $0.8 \mathrm{~mm}$. wider than the average male. If anyone therefore wants to breed Pomatias it is probably safe to assume that the largest shells are females and the smallest males; about two-thirds might from their size be of either sex.

It would be a matter of much interest to determine whether there is any size selection in mating. In the present series only six pairs were taken in cop.; in each case the male was smaller than the female :-

$\begin{array}{cccc}\text { Male. } & \text { Female. } & \text { Male. } & \text { Female. } \\ 13 \cdot 5 & 13 \cdot 7 & 13 \cdot 2 & 15 \cdot 2 \\ 12 \cdot 6 & 13 \cdot 7 & 13 \cdot 4 & 14 \cdot 6 \\ 13 \cdot 4 & 14 \cdot 6 & 12 \cdot 7 & 13 \cdot 5\end{array}$

\section{Tumidity of Shell.}

Taking next the question whether the tumidity ( $\frac{\text { altitude }}{\text { diameter }}$ index) differs in the two sexes, we have the following figures, the shells being grouped by altitude into half-millimetre groups :-

\begin{tabular}{|c|c|c|c|c|c|c|c|}
\hline & ALES. & & & & MaLes. & & OTAL. \\
\hline $\begin{array}{l}\text { Group. } \\
12 \cdot 0-12 \cdot 4\end{array}$ & $\begin{array}{r}\text { No. } \\
6\end{array}$ & $\begin{array}{r}\text { Mean i } \\
(13\end{array}$ & dex. & No. & Mean index. & No. & $\begin{array}{l}\text { Mean index. } \\
\text { (139) }\end{array}$ \\
\hline $12 \cdot 5-12 \cdot 9$ & 46 & 13 & & - & - & 46 & 139 \\
\hline $13 \cdot 0-13 \cdot 4$ & 71 & 14 & & 2 & (141) & 73 & 140 \\
\hline $13 \cdot 5-13 \cdot 9$ & 50 & 14 & & $2 \overline{6}$ & 139 & 76 & 140 \\
\hline $14 \cdot 0-14 \cdot 4$ & 10 & 14 & & 52 & 139 & 62 & 140 \\
\hline $14 \cdot 5-14 \cdot 9$ & 1 & $(14$ & & 33 & 140 & 34 & 140 \\
\hline $15 \cdot 0-15 \cdot 4$ & - & - & & 16 & 142 & 16 & 142 \\
\hline $15 \cdot 5-15 \cdot 9$ & 一 & - & & 4 & (143) & 4 & (143) \\
\hline Total. & 184 & 140 & & 133 & 140 & 317 & 140 \\
\hline & $\frac{\text { itude }}{\text { meter }}+100$ & & Males. & & emales. & Total. & \\
\hline & $130-132$ & & 6 & & 6 & 12 & \\
\hline & $133-135$ & & 13 & & 11 & 24 & \\
\hline & $136-138$ & & 43 & & 31 & 74 & \\
\hline & $139-141$ & & 61 & & 35 & 96 & \\
\hline & $142-144$ & & 44 & & 36 & 80 & \\
\hline & $145-147$ & & 14 & & 13 & 27 & \\
\hline & $148-150$ & & 2 & & 1 & 3 & \\
\hline & $151-153$ & & 1 & & 0 & 1 & \\
\hline Mean & & . & $139 \cdot 91$ & & $139 \cdot 86$ & $139 \cdot 88$ & \\
\hline Standar & leviation & a & $3 \cdot 645$ & & $3 \cdot 951$ & $3 \cdot 165$ & \\
\hline Coefficie & of variat & tion & $2 \cdot 6$ & & $2 \cdot 8$ & $2 \cdot 3$ & \\
\hline
\end{tabular}

Taking the results as a whole, or dealing only with the groups $(13.5$ and $14.0 \mathrm{~mm}$. altitude) which contain a fair number of both males and females not differing very grossly in size, there is no evidence that there is any sexual difference in tumidity. The index has a low variability, ${ }^{1}$ and the evidence that it varies with size is indefinite, though there is some suggestion that the larger shells are relatively more slender.

1 Corresponding with a high correlation $(+0.92)$ between altitude and diameter. 
III. Weight of Shelr.

The average weights of the shells with opercula (dried at $100^{\circ} \mathrm{C}$.) showed no difference between males and females except that due to size. $^{1}$ In the $13.5 \mathrm{~mm}$. group the sizes and weights are identical: in the $14 \cdot 0 \mathrm{~mm}$. group the females $(14 \cdot 2 \times 10 \cdot 1)$ had larger shells than the males $(14.0 \times 9 \cdot 9)$. Hence we may conclude that there is no sexual difference in shell thickness.

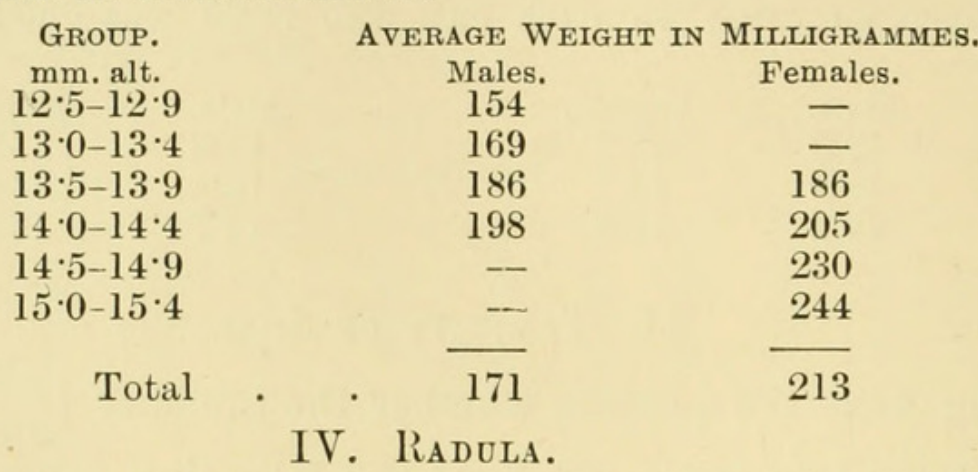

The bodies were used for various purposes; from 185 (112 males, 73 females) the radulæ were extracted by boiling with caustic soda and mounted in Farrant's solution. No sexual difference in the shape or character of the teeth could be made out, and beyond three cases with multicuspid centrals there seemed to be no gross variations; for numerical examination the length of the radula and the number of transverse rows of teeth were determined. The length is given in arbitrary units, $12 \cdot 8$ of which equal $1 \mathrm{~mm}$.

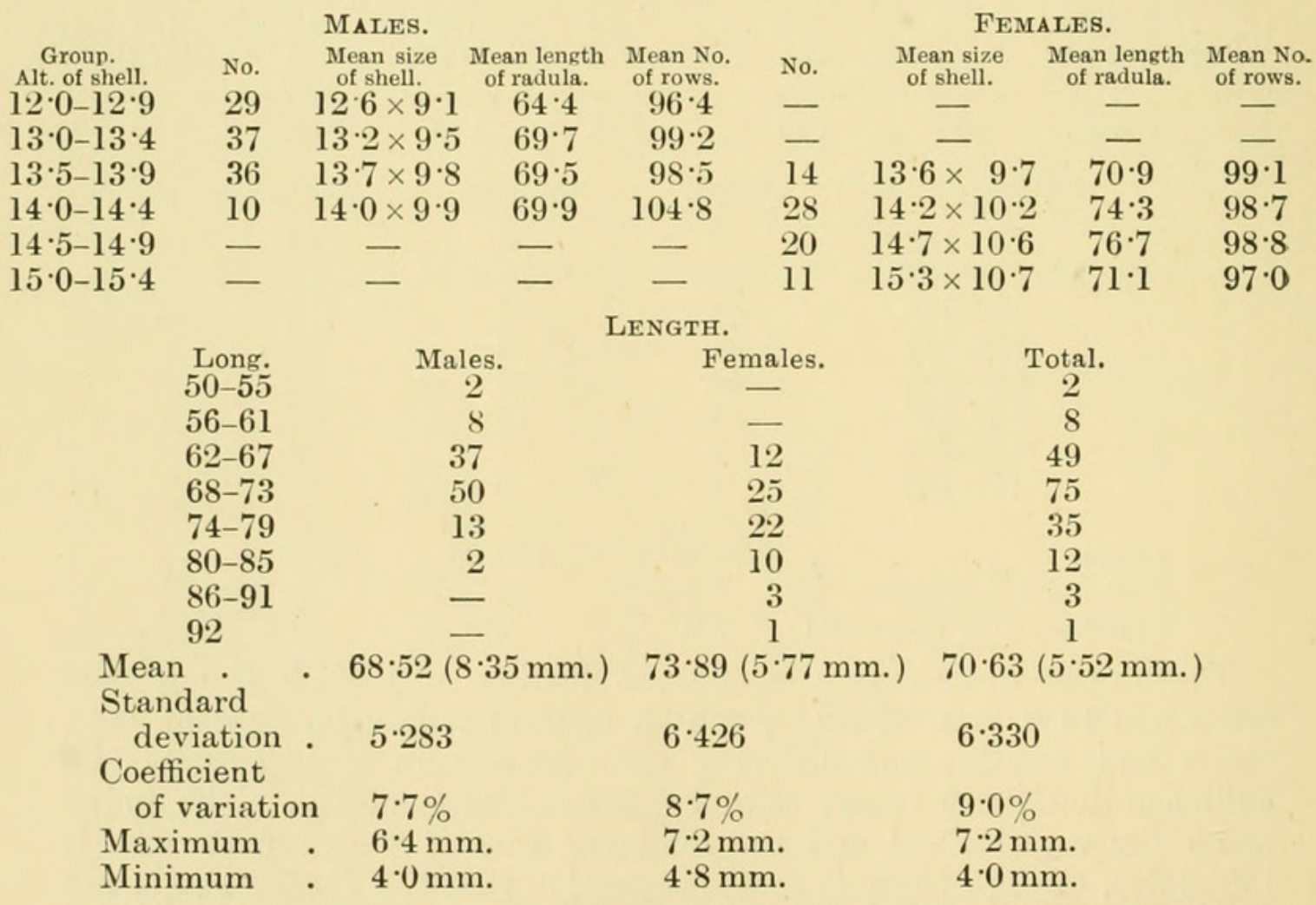

1 The weights are nearly proportional to the calculated shell volumes, the ratio volume to weight varying only from $2 \cdot 5$ to $2 \cdot 6$ on passing from the smallest males to the largest females. 


\begin{tabular}{|c|c|c|c|c|}
\hline & & JUMBER & ws. & \\
\hline & Rows. & Males. & Females. & Total. \\
\hline & $78-85$ & 12 & 3 & 15 \\
\hline & $86-93$ & 23 & 21 & 44 \\
\hline & $94-101$ & 40 & 19 & 59 \\
\hline & $02-109$ & 23 & 22 & 45 \\
\hline & $10-117$ & 10 & 5 & 15 \\
\hline & $18-125$ & 2 & 2 & 4 \\
\hline & $26-129$ & 2 & 1 & 3 \\
\hline ean. & . & $98 \cdot 25$ & $98 \cdot 29$ & $98 \cdot 27$ \\
\hline andard & deviation & $10 \cdot 07$ & $9 \cdot 61$ & $9 \cdot 90$ \\
\hline Coefficient & $t$ of variation & $10 \cdot 2 \%$ & $9 \cdot 8 \%$ & $10 \cdot 1 \%$ \\
\hline Maximum & 1. & 129 & 127 & 129 \\
\hline Minimum & . & 78 & 79 & 78 \\
\hline
\end{tabular}

These figures show that the females have a larger radula than the males but about the same number of transverse rows; in the males the number of rows appears to increase as the shell becomes larger, while in the females it remains the same or even becomes less. Whether the difference in length is due to the larger size of the females is uncertain without more ample data for males and females of equal size. ${ }^{1}$ Relatively to the volume of the shell and the weight of the body the female radula is obviously short and has few rows, but the same is true of the larger males and females compared with smaller individuals of the same sex. The ratio of the volume of the female shell to that of the male is about $130: 100{ }^{2}$ The average weights of a series of bodies dried at $100^{\circ} \mathrm{C}$. are given below, the general ratio being $138: 100$. On the whole, therefore, while the radula of the females is slightly but clearly different from that of the males, it is hardly legitimate to call it a sexual difference without clearer exclusion of the size factor.

\begin{tabular}{|c|c|c|c|c|c|c|}
\hline \multicolumn{3}{|c|}{ MaLes. } & \multirow[b]{2}{*}{$\begin{array}{l}\text { Average weight } \\
\text { of body : mg. }\end{array}$} & \multirow[b]{2}{*}{ No. } & Females. & \multirow[b]{2}{*}{$\begin{array}{l}\text { Average weight } \\
\text { of body : mg. }\end{array}$} \\
\hline Group. & No. & $\begin{array}{l}\text { Average size } \\
\text { of shell. }\end{array}$ & & & $\begin{array}{l}\text { Average size } \\
\text { of shell. }\end{array}$ & \\
\hline $12 \cdot 0-12.9 \mathrm{~mm}$ & 17 & $12 \cdot 6 \times 8 \cdot 9$ & 48 & - & - & - \\
\hline $13 \cdot 0-13 \cdot 9$ & 46 & $13 \cdot 3 \times 9 \cdot 5$ & 53 & 13 & $13.6 \times 9.8$ & 62 \\
\hline $14 \cdot 0-14 \cdot 9$ & 6 & $14 \cdot 1 \times 9 \cdot 8$ & 58 & 35 & $14 \cdot 4 \times 10 \cdot 2$ & 72 \\
\hline $15 \cdot 0-15 \cdot 9$ & - & - & - & 11 & $15.3 \times 10 \cdot 7$ & 87 \\
\hline
\end{tabular}

\section{Sex of Imatature Specimens.}

Those of the immature specimens which were $10 \mathrm{~mm}$. or more in altitude were examined for sex and gave 40 per cent males, ${ }^{3}$ distributed as follows :-

${ }^{1}$ It is obviously illegitimate to bring immature specimens into the comparison, the radula being a feeding organ, and the amount of food required being presumably quite different in growing and adult individuals.

2 i.e. assuming the shell is a regular cone with a base equal to the measured diameter and a height equal to the measured altitude.

3 This does not satisfy the statistical test that there are really fewer males in the immature than in the mature specimens ( 58 per cent). 


\begin{tabular}{|c|c|c|c|}
\hline Group. & Males. & Females. & Total. \\
\hline $10 \mathrm{~mm}$. & 8 & 9 & $\begin{array}{l}17 \\
21\end{array}$ \\
\hline $\begin{array}{l}11 \\
12\end{array}$ & $\begin{array}{r}9 \\
11\end{array}$ & $\begin{array}{l}12 \\
15\end{array}$ & $\begin{array}{l}21 \\
26\end{array}$ \\
\hline 13 & 3 & 9 & 12 \\
\hline 14 & 0 & 1 & 1 \\
\hline Total & 31 & 46 & 77 \\
\hline
\end{tabular}

\section{Colour Variation in Shell.}

Among the 317 mature specimens were 64 (20 per cent) of the pale form (var. ochroleuca) and in the 77 immature 16 (21 per cent); there is no evidence that this variety has any relationship to size or sex :-

MaLes. Group. Total No. $\begin{gathered}\text { No. of } \\ \text { ochroleuca. }\end{gathered}$ Total No. $\begin{gathered}\text { No. of } \\ \text { ochroleuca. }\end{gathered}$ Total No. $\begin{gathered}\text { No. of } \\ \text { ochroleuca. }\end{gathered}=$ per cent.

$10 \mathrm{~mm}$. $\quad \mathrm{s}$

$11 \quad 9$

$12 \quad 63$

$13 \quad 124$

$14 \quad 11$

15

Total . $\overline{215}$ ochroleuca.

9
12
15
37
86

1

15

2

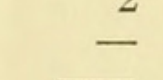

$39 \overline{(18} \%)$
9

2

1

1

78

$10 \quad 161$

$21 \quad 97$

20

179
3

$\frac{3}{41(22 \%)} \quad \frac{20}{394}$
Total.
$12 \%$ 10

27

18

24

15

315

80

\section{Summary.}

(a) Females are larger than males.

(b) There is no difference in shape nor, allowing for size, in weight.

(c) The female radula is longer, but has not more teeth, than the male radula.

(d) The var. ochroleuca has no sexual significance. 


\section{$2 \mathrm{BHL}$ Biodiversity Heritage Library}

Boycott, A. E. 1917. "ON SEXUAL CHARACTERS IN THE SHELL AND RADULA OF POMATIAS ELEGANS (MÜLLER)." Proceedings of the Malacological Society of London 12, 127-132.

View This Item Online: $\underline{\text { https://www.biodiversitylibrary.org/item/53698 }}$

Permalink: https://www.biodiversitylibrary.org/partpdf/203181

\section{Holding Institution}

Smithsonian Libraries

\section{Sponsored by}

Smithsonian

\section{Copyright \& Reuse}

Copyright Status: Public domain. The BHL considers that this work is no longer under copyright protection.

This document was created from content at the Biodiversity Heritage Library, the world's largest open access digital library for biodiversity literature and archives. Visit BHL at https://www.biodiversitylibrary.org. 